УДК: 72.036

ББК: 85.11085 .118

A43

DOI: $10.18688 / \mathrm{aa} 188-6-56$

Irina Seits

\title{
Invisible Avant-Garde and Absent Revolution: Walter Benjamin's New Optics for Moscow Urban Space of the 1920s
}

Walter Benjamin spent the fall and winter of 1926-1927 in Moscow. His experience and observations were recorded in "Moscow Diary" [2] and essay "Moscow" (1927). In the present paper I refer to the latter text, where Benjamin reflected on the space of the Soviet state capital that was undergoing severe transition. Without even mentioning avant-garde architecture that was being constructed in his presence to transform the new state's living space on all levels, Benjamin left deep analysis of Moscow's post-revolutionary urban constitution, revealed its nature, and predicted its future.

While recording those vast transformations that he had witnessed during his stay, Benjamin described them neither in terms of the new functionalist architecture, nor through reflections on demolition of Empire's architectural symbols. He turned to other features and spatial dimensions that were not directly related to any particular architecture, such as mobility, rhythm, aura, and through which he fully revealed the reformation of Moscow space that was initiated by functionalists under support by the new regime.

The "Moscow" [4] essay, along with another text that I refer to, "Experience and Poverty" (1933) [5], enables for the deeper analysis of Avant-garde aesthetics, of its origin, development, and end, and which is the major objective of the present article.

The Essay "Moscow" that is taken here for closer reading is based on the "Moscow Diary" that Benjamin wrote during his stay in the new capital in December 1926 and January 1927. His immediate impressions and experiences along with highly complicated relationship with Asja Lacis, the lover and, later, the wife of Benjamin's friend, Bernhard Reich, the Austrian playwright, were recorded in the diary that was first published in Germany only in 1980, after Asja’s death in Russia [1]. The Essay "Moscow" was written by Benjamin for "Die Kreatur" journal as part of his agreement with Buber that was made before he went to Moscow [17, p. 83]. The first English edition of the "Moscow" essay, where the hardships of Benjamin's private life were set aside to give full way to his reflections on Moscow as urban and spatial phenomenon, was first published in 1978 [7].

The interest to the works by Benjamin has been rising tremendously through the last decade, yet the present article introduces an attempt to take the "Moscow" essay to the close reading with an idea to restore and analyse the urban space of the new Soviet capital of the late 1920s. Here the original text becomes a tool and the spectacles that are borrowed from 
an "attentive viewer" [4, p. 22] in order to reflect on the transformations in the living space of Moscow in the decade between the Revolution and the followed totalitarisation of the state. Those are Benjamin's precise remarks and observations that allow for deeper reflection on the further destiny of modernism in Russia and globally, which, together with his genius ability to grasp the concrete, opens up to analysis of the urban space produced in that era [3].

\section{Invisible Revolution and Resistance to Avant-Garde}

The period of Benjamin's visit to Moscow is still the era of Constructivism in architecture, and yet Benjamin discovers that "constructivists, suprematists, abstractionists who under War Communism placed their graphic propaganda at the service of the Revolution have long since been dismissed" [4, p. 39]. Even though the official abandonment happened only 5 years later, after the declaration of the course towards socialist realism, Benjamin had already noticed that there was no space for the voice of constructivism on Moscow streets.

Although the most famous objects of Avant-garde were yet to come, at the time of Benjamin's stay there, Moscow was a huge construction site, where a number of housing estates ("zhilmassivs"), factory-kitchens, administrative buildings, trade houses, garages and industrial objects were being constructed [9].

Still, neither the general constructivist practice, nor the masterpieces of Avant-garde that continued appearing in the Soviet capital till the mid-thirties, had turned Moscow to the city of modernism. Brilliant pieces of Avant-garde remained the islands on the city's body, but they failed neither to penetrate its very nature nor to transform its absolute urban space [14]. Moscow remained outlined by the architecture of the pre-revolutionary ages on one side, and by the architectural embodiments of the Socialist realism on the other [13].

Even today there are not many monuments of Avant-garde that stand as architectural symbols of Moscow. One can imagine Melnikov's house and workers' clubs by Rusakov and Golosov located anywhere, not precisely in Moscow. Most people who are familiar with images of Russia will name Moscow if shown the pictures of Kremlin or St. Basil's Cathedral. But how many would do so, if given an image of one of the constructivist gems? There are hardly any Avant-garde masterpieces that symbolise Moscow [10].

Yet those are the "Seven Sisters" born in the followed era of Socialist realism that represent Russian capital along with Kremlin and St. Basil's Cathedral, and which are perceived as Moscow brand images. Stalin's neo-classicism is more characteristic to the portrait of Moscow, than constructivist dom-kommunas and workers' clubs.

One could argue for the Lenin's Mausoleum that was built in the Avant-garde decade (1929-1930) by Alexander Shchusev as for one of the most prominent and symbolic buildings of Moscow. Yet Mausoleum stands for the memory of all Soviet ideology, rather than for the modernist aesthetics. It is inseparable from the Red Square and Kremlin wall behind it. Mausoleum represents not a piece of constructivist architecture (and it is hardly ever referred to as to a work of constructivism), but it is the Soviet Temple, a sacral building, which does not manifest its Avant-garde nature, but serves as Temple for the God of the Soviets. The architecture of Mausoleum is not more Avant-garde than that of Egyptian pyramids, which are pure and elementary in their forms and which merge entirely with their function - to be the tomb of the Pharaoh's body. 
Shchusev found the only acceptable form for the tomb that was beyond time and style; it preserved grandeur and sacristy of petrified space and its content - the Lenin's body. The forms of the Mausoleum are neither modernist, nor contemporary - the are timeless. Benjamin notices that Lenin's name "grows and grows" after his death [4, p. 45]. The cult of Lenin becomes an icon: "One finds shops in which it can be bought in all sizes, poses, and materials. It stands as a bust in the Lenin niches, as a bronze statue or a relief in the larger clubs, as a life-size portrait in offices, as a small photo in the kitchens, washrooms, and storage rooms" [4, p. 45].

Lenin's images replaced Orthodox icons, and his body found rest within the new church of the Soviets. The Mausoleum was to be a building that could never look outdated. It could not represent any temporal architectural fashion or style that could be once abandoned. It should be disconnected from the contemporaneity and deliver itself to eternity. The architect Shchusev had built nearly forty Christian churches before the Revolution; later he adjusted his practice to the Avant-garde aesthetics and designed some bright examples of constructivism. After the prohibition of Avant-garde, he became a successful architect of Socialist realism. Shchusev had a feeling and skill to design a piece of sacral architecture that would be impossible to remove from the Red Square even after the change of the regime. Lenin's Mausoleum is hardly a work of Avant-garde despite of the clarity and simplicity of its forms. It is in this denial of connection to the immediate space and time, to the beat of the days, which Moisey Ginsburg defined as one of the major features of constructivism [11], where Shchusev broke up with modernity.

Shchusev managed to overcome the opposition between space and history that was mentioned by Benjamin regarding the image of Lenin: “...in the optics of history — opposite in this to that of space - movement into the distance means enlargement" [4, p. 45]. The tomb gives architectural forms to the memory of Lenin and to his image, and it has grown along with his name.

Post-Revolutionary architecture in Russia is the most immediate architecture; it requires not the contemplation but immediate experience of its space, forms and rhythms. Inhumanly intensified mobility of life demanded for the immense mobility of architecture and the living space that it produced. Benjamin notices in his essay the "unconditional readiness for mobilisation" [4, p. 1] of Moscow population. Everything moves and changes, everything and everybody are involved into certain transition of practices and meanings. The mobility and intensity of life possess the nature of laboratory experimentation "to the point of exhaustion", and "no organism, no organisation, can escape this process" [4, p.28]. Benjamin continues that "employees in their factories, offices in buildings, pieces of furniture in apartments are rearranged, transferred, and shoved about" [4, p. 28-29].

The temporality of the present conditions of existence and the tense feeling of awaiting forces people to divorce with their past and become the new barbarians, who, according to Benjamin, are inevitable inhabitants of modernity. The demanded inhabitant of the new reality was the "naked man of the contemporary world who lies screaming like a newborn babe in the dirty diapers of the present" [5, p. 733]. A man should have returned to the very beginning of his existence - to the barbaric state of a newborn baby, and so the architecture should have returned to the null of its form as was proposed in the "Black Square" by Malevich.

For Benjamin Moscow is full of the barbaric sense, where "goods burst everywhere from the houses" [5, p. 733]: they are sold in the streets, carried along, lie in the snow. One of the features 
of new barbarism is the fullness of Moscow streets that he compares to the "princely solitude, princely desolation" that "hang over the streets of Berlin" [4, p. 23]. After Moscow, Berlin is a deserted city [4, p. 23]. Barbarians, just like children, are hostile to solitude, they fear it. The old, experienced and noble need solitude, while young, strong and inexperienced are looking for abundance and fullness of living.

Benjamin calls Moscow that reveals the peasant origin of its new population a "gigantic village" [4, p.33].Fascinated by the naïve colourfulness of the cheap trade, he describes the objects of childhood sold on the streets, such as toys and fruit. The city is returning to its preurban "childhood state": "the instant you arrive, the childhood stage begins" [5, p. 22]. One should learn to walk anew to proceed through the streets and needs to learn seeing Moscow in order to comprehend its colours that "converge prismatically here, at the centre of Russian power" [4, p. 24].

Benjamin found no Revolution in the Russian capital, but only its snatches hanging over the windows: "You need to know Russia to understand what is going on in Europe" [4, p.22]. Moscow served as a certain prediction of what might have happened in Europe if she went similar way. Benjamin described Moscow as "a corporation of the dying" [4, p. 27]. The city was regarded by him as being in a state of transition from life to death, from Revolution to nonRevolution, of being in a state of a failing Revolution.

The experimental Avant-garde space in Russia was to be inhabited necessarily with migrants, which, as Mark Mejerovich claims, was the conscious policy of the state [15]. Majority of the new population of the towns, where constructivists realised their projects, were people who had been previously displaced from their original living spaces. They could have been brought from far away or migrate within same region, city or even apartment, which became a communal flat through the program of "uplotnenie" (tightening), but in either way they had already parted with their previous lives [8].

The new environment forced them to migrate all the time and in all dimensions. One could be moved from a village to a town; his profession could be changed from a farmer to a worker; his working space of a farmer's field replaced with a plant; his living space of a hut substituted with a room in kommunalka; his family outlined with random neighbours. He realised that the pause in the row of transformations of his living was temporal and could continue any moment with anything from imprisonment to the communist leader's career.

Constructivists captured and aesthetically reinterpreted the temporality and fragmentation of the new living. Most types of buildings that they developed resembled social features of the period and were based on the type of a barrack [15]. Dom-kommuna, obschezhitie those were the types of dwellings that were based on transitional character of a barrack, where sleeping cells were arranged along corridors and required collective forms of living in large communities, which eliminated notions of traditional household, home and family. Everyday living practices were fragmented to separate spaces that provided control over routines by collectiveness of their nature and unavoidable publicity: meals were to be eaten in factorykitchens and hygienic procedures realised in collective bath-houses, etc. People were constantly moving in and out of those constructions, possessing high level of mobilisation and mobility that was noticed by Benjamin during his visit to Moscow. 


\section{Concluding remarks}

Benjamin does not draw any conclusions on his stay in Moscow. He leaves the reader of his diary with the image of Lenin sitting at the table: "his gaze is turned, certainly, to the far horizon; but the tireless care of his heart, to the moment" [4, p.46]. Here Benjamin ends with a definition of the living in his age, which becomes one of the hallmarks of the essay "Experience and Poverty", and which will be written in few years: "A total absence of illusion about the age and at the same time an unlimited commitment to it" [5, p.733]. The image speaks directly on that complete disillusionment, concern and yet commitment to the age that Lenin and the whole revolutionary Avant-garde era had ended up with before their death.

Staying in Moscow three years after Lenin died, Benjamin found neither Revolution, nor Avant-garde. The moment of commitment to modernity had passed, it was not present in the Soviet capital where everyone was only digging for power "from early till late" [4, p. 36].

Benjamin feels the mourning for the lost hopes among the makers of Revolution. The death of Lenin marked the end of the era of possibilities for the future: "For Bolsheviks, mourning for Lenin means also mourning for Communism" [4, p. 45].

The main transformation of Moscow space was achieved through demolition of borders between inner and outer spaces [14], between interior and exterior: "Bolshevism has abolished private life" [4, p.30], which disconnected living space from its traditional material frames. It turned the living space inside out: "through the hall door, one steps into a little town" [1, p. 30]. In the presence of Benjamin, Moscow, along with the rest of the country, was going through the collectivisation and communalisation of its space, where, as Hilde Heynen noted, the "public openness, transparency, and permeability" became the "conditions of everyday life" [12, 119]. Yet, that process did not lead to the classless and open society; on the contrary, Benjamin identified Communist Russia as "not only a class but also a caste state" [4, p. 35], meaning that "the social status of a citizen is determined not only by the visible exterior of his existence - his clothes or living place - but exclusively by his relations to the party" [4, p. 35]. Those relations outlined the borders of penetrability through and within the space of existence. They were transparent and yet hard, just as sober glass praised by functionalists.

Those borders formed isolated islands that were inhabited by the members of the party in which favour the state adjusted [15]. The party was the space where power collected and concentrated. Benjamin noticed that party demonstratively retreated itself from money, leaving it to the NEP-men [4, p. 35], but it was only for the time being. Benjamin recognised that new economic policy that Soviet Russia had already accepted was fatal to the whole way of its being: "Should the European correlation of power and money penetrate Russia, too, then perhaps not the country, perhaps not even the party, but Communism in Russia would be lost" [4, p. 36]. The prediction inevitably came true during Perestroika; yet in the 1930s it was the totalitarisation of state and concentration of power and money in the hands of the party that managed to postpone the collapse of regime for several decades [9].

Russian constructivists followed the route of the communists' intuitive delay of their end. They were faking their own methods of the new space production [14]. The ribbon windows that became the brand symbol of the method were very often imitated on the facades due to the shortage of glass production. That imitation, which demonstrated the lack of resources to build the new reality bitterly symbolised the upcoming failure. 
Constructivists possessed unlimited commitment to the age, and yet they lived in illusion. They left oases of architecturalised illusions in Moscow, but did not manage to reform its urban space.

Both Revolution and Avant-garde that once were allies, proved temporality of their nature. Neither the ideal model of society nor ideal organisation of the living space was reached. It was a global experiment that had turned the country into the huge laboratory table. The very high level of intensity of transformations and the re-appropriation of space along with the immediacy of its very process were characteristic to the period [14]. The new space was not only being produced, but it was first of all being searched for within the old milieu. As Benjamin noticed, the new reality, intentions and practices "often have no site of their own, being held in corners of noisy editorial rooms, or at cleared table in a canteen" [4, p. 31].

The living experience was traumatic for majority of the Soviets in the 1920s, though not necessarily connected to the Avant-garde experiments. Still Russian constructivism is associated generally with its age of the first post-revolutionary decade, and thus it carries responsibility for all housing solutions of the time that were realised by the state authorities in the processes of collectivisation and industrialisation [15]. The historical period of Russian Avant-garde was filled to the brim with dramatic events that contradicted its very aesthetics. The architectural space produced in the 1920s evokes reference to the period that apart from the brilliant futuristic experiments is connected with the red and white terror, civil war and humanitarian catastrophes of the post-revolutionary age [16].

Russian constructivism was born in the 1920s, and it failed to make it to the next decade. The snatches of Avant-garde that reached our times still refer to the past; they are disconnected from the present and thus perceived as outdated. Their aura is very decently felt by general public in Russia. The tenants who live in the buildings constructed by functionalists have never explored them in their complete state. They have never had a chance to distant themselves from discomfort of living in buildings that were never completed before they started to decay after the decades of neglect, symbolising another failed utopia.

\section{References}

1. Benjamin W. Moskauer Tagebuch. Frankfurt, Suhrkamp Verlag Publ., 1980. 220 p. (in German).

2. Benjamin W. Moscow Diary. Harvard, Harvard University Press Publ., 1986. 156 p.

3. Benjamin W. The Arcades Project. Cambridge, The Belknapp Press of Harvard University Press Publ., 1999. $1098 \mathrm{p}$.

4. Benjamin W. Moscow. Benjamin W. Selected Writings. Vol.2. 1927-1940. Harvard, Harvard Univ. Press Publ., 1999, p. 22-46.

5. Benjamin W. Experience and Poverty. Benjamin W. Selected Writings. Vol.2. 1927-1940. Harvard, Harvard University Press Publ., 1999, pp. 731-736.

6. Benjamin W. Reflections: Essays, Aphorisms, Autobiographical Writings. New York, HBJ Publ., 1978. 348 p.

7. Bowlt J. Russian Art of Avant-Garde: Theories and Criticism 1902-1934 (Documents of Twentieth-Century Art). London, Thames \& Hudson Publ., 1988. 371 p.

8. Boym S. Common Places: Mythologies of Everyday Life in Russia. Cambridge, Harvard University Press Publ., 1995. $384 \mathrm{p}$.

9. Cooke C. Russian Avante-Garde: Theories of Art, Architecture, the City. New York, St. Martins Press Publ., 1995. $144 \mathrm{p}$.

10. Clark K. Moscow, the Fourth Rome: Stalinism, Cosmopolitanism and the Evolution of Soviet Culture, 19311941. Cambridge, Harvard University Press Publ., 2011. 432 p. 
11. Ginsburg M. Stil' i Epokha / Style and Epoch. Moscow. Gosudarstvennoe Izdatel'stvo, 1924. 238 p.

12. Heynen H. Architecture and Modernity. Cambridge, MIT Press Publ., 1999. 276 p.

13. Kiaer C. Imagine No Possessions. Cambridge, MIT Press Publ., 2005. 326 p.

14. Lefebvre H. The Production of Space. Hoboken, Wiley-Blackwell Publ., 1992. 464 p.

15. Mejerovich M. Gradostroitel'naia politika $v$ SSSR (1917-1929). Ot goroda-sada kvedomstvennomu rabochemu posyolku (The City-Building Policy in the USSR (1917-1929). From the Garden City to the Departmental Workers' Village). Moscow, NLO, 2017. 352 p. (in Russian).

16. Roman G.; Marquardt V. (eds.). Avant-Garde Frontier: Russia Meets the West 1920-1930. Gainesville, University Press of Florida Publ., 1992. 312 p.

17. Wellek R. Benjamin's Diary. The New Criterion, 1986, vol. 5, no. 3, p. 83.

Title. Invisible Avant-Garde and Absent Revolution: Walter Benjamin's New Optics for Moscow Urban Space of the 1920s.

Author. Seits, Irina Sergeevna - Ph. D. student. Södertörn University, Alfred Nobels alle 7, Fleminsberg, 14189 Stockholm, Sweden. irina.seits@sh.se

Abstract. Walter Benjamin spent the fall and winter of 1926-1927 in Moscow. His experience and observations were recorded in "Moscow Diary" and essay "Moscow" (1927). In the present paper, the author refers to the latter text, in which Benjamin reflected on the space of Soviet capital that was undergoing severe transition. Without even mentioning Avant-garde architecture that was being constructed in his presence and that was transforming the living space of the new state on all levels, Benjamin left deep analyses of Moscow's post-revolutionary urban constitution, revealed its nature, and predicted its future.

Benjamin came to Moscow to observe the Revolution in action, but could not find it. Instead, he saw Constructivism as already dismissed. While recording those huge transformations that he witnessed during his stay, Benjamin had not described them either in terms of new functionalist architecture, or through the reflection on demolition of Empire's architectural symbols. He turned to other features and spatial dimensions that were not directly related to any particular architecture, such as mobility, rhythm, aura and through which he fully revealed reformation of Moscow space that was initiated by functionalists and supported by the new regime.

The "Moscow" essay along with another text that I refer to, "Experience and Poverty" (1933), enable for deeper analyses of Avant-garde aesthetics, of its origin, development and end, which is the major objective of the present article.

Keywords: Walter Benjamin; Russian Revolution; Moscow; Avant-garde; constructivism, living space; new barbarism; modernist architecture; urban history.

Название статьи. Невидимый Авангард и потерянная Революция: новый взгляд Вальтера Беньямина на городское пространство 1920 -х годов.

Автор. Сейц Ирина Сергеевна - аспирант. Университет Содерторн, Альфред Нобель алле, Флемингсберг, Стокгольм, Швеция, 14189. irina.seits@sh.se

Аннотация. Вальтер Беньямин жил в Москве осенью и зимой 1926-1927 гг. Свои впечатления он описал в «Московском дневнике» и эссе «Москва» (1927). Последний текст посвящен столице как исключительно жилому и пространственному феномену. В настоящей работе я обращаюсь к детальному прочтению этого текста с целью анализа Москвы как среды, где создавалась новая советская реальность, и где Беньямин надеялся увидеть Революцию в действии.

Именно в то время в Москве эстетика конструктивизма воплощалась в знаменитые архитектурные шедевры, а традиционное жилое пространство реформировалось лучшими архитекторами авангарда. Беньямин не нашел Революцию в Москве, но обнаружил небывалую концентрацию и интенсивность происходящих конструктивных трансформаций городской среды. Он не описал их ни с позиций функционализма, который считал уже пораженным, ни с позиций разрушения архитектуры старого мира. Беньямин обратился к иным, внеархитектурным свойствам московского пространства. Однако, он оставил глубокий анализ реформаций, происходивших в московской среде, которые были начаты авангардом и поддержаны новым режимом.

Эссе «Москва» позволяет глубже понять эстетику авангарда, ее истоки, развитие и конец, не смотря на то, что сам авангард и его архитектура исключены из поля зрения автора. Однако, гениальная способность «увидеть сущее» в самом пространстве города позволила мыслителю написать многогранную и глубокую картину Москвы. 
Взаимодействие «нового человека» с пост-революционной реальностью и восприятие им нового жилого пространства, сформированного 1920-е гг. являются объектами анализа настоящей статьи.

В данном исследовании я анализирую процессы трансформации старого и формирования нового жилого пространства в 1920-е гг. Инициированные Октябрьской революцией и поддержанные авангардом, они с глубоким вниманием, восхищением и, одновременно, с предчувствием грядущего краха были описаны одним из величайших современников эпохи.

Ключевые слова: Вальтер Беньямин; русская революция; Москва; авангард; жилое пространство; новое варварство; бедность опыта; конструктивизм; модернистская архитектура; история градостроительства. 